\title{
Sinapic Acid Degradation by the Yeast Rhodotorula glutinis
}

\author{
By JUGAL K. GUPTA, *† CORNELIA JEBSEN AND HELMUT KNEIFEL \\ Institute for Biotechnology, Kernforschungsanlage, Jülich, FRG
}

(Received 15 April 1986)

\begin{abstract}
The degradation of sinapic acid, a monomer of hardwood lignins, by the yeast Rhodotorula glutinis was studied. Syringic acid, 3-O-methyl gallic acid, gallic acid and 2,6-dimethoxy-1,4benzoquinone were identified as degradation products. Glucose was shown to be required for the demethylation of the methoxy groups on the ring. Unlike in the bacterium Pseudomonas putida, ring cleavage seemed to occur via gallic acid and not via methyl gallic acid. Cell-free oxidative decarboxylase (hydroxylase) activity was detected; this enzyme might be ultimately responsible for the formation of dimethoxyquinone.
\end{abstract}

\section{INTRODUCTION}

One reason for studying the microbial metabolism of aromatic compounds is to understand the reactions involved in the degradation of lignin. As hardwood lignins contain syringic-type structural elements (Adler, 1977; Nimz, 1974), syringic acid and sinapic acid can serve as monomeric models for these degradation studies. Degradation of syringic acid both by bacteria (Sparnins \& Dagley, 1975) and fungi (Eriksson et al., 1984; Iyayi \& Dart, 1982; Haider \& Trojanowski, 1975) has been reported. In the course of degradation studies of sinapyl alcohol, the wood-rotting fungus Schizophyllum commune was shown to be able to degrade sinapic acid (Iyayi \& Dart, 1982). There is, however, no detailed report in the literature on the metabolism of sinapic acid by a yeast. Yeasts of the genus Rhodotorula have been shown to be able to degrade chlorophenols (Walker, 1973) as well as vanillic and ferulic acid which represent the guaiacyl (soft-wood) lignins (Cain et al., 1968). The isolation of Rhodotorula grinbergsii from decaying wood (Ramirez \& Gonzalez, 1984) indicates that this yeast might be involved in the process of wood decay. We now report on the degradation of sinapic acid by the yeast Rhodotorula glutinis.

\section{METHODS}

Organism. The pink-coloured yeast used in this study was identified by the Centraalbureau voor Schimmelcultures, Baarn, Holland, as Rhodotorula glutinis (Fresenius) Harrison; it was isolated from the soil around a paper mill in India (Jain, 1981).

Chemicals. Most of the chemicals used were of reagent grade and are commercially available. Sinapic and syringic acid were from Carl Roth; gallic acid was from Merck. 2,6-Dimethoxy-1,4-hydroquinone was a gift from Professor T. Higuchi, Kyoto University, Japan; 2,6-dimethoxy-1,4-benzoquinone was a gift from Dr. P. Ander, Swedish Forest Products Laboratory, Stockholm, Sweden. 3-O-Methyl gallic acid was synthesized in the laboratory by partial demethylation of syringic acid $(600 \mathrm{mg})$ in $5 \mathrm{ml}$ of $48 \% \mathrm{HBr}$ (in water)/acetic acid $(1: 1, \mathrm{v} / \mathrm{v})$ heated for $1 \mathrm{~h}$ at $100^{\circ} \mathrm{C}$. The product was purified by preparative reverse-phase HPLC using a RP-18 column $(25 \times 1.6 \mathrm{~cm})$ and $15 \%(\mathrm{v} / \mathrm{v})$ methanol in water as eluent. [carboxy-14 $\mathrm{C}$ ]Syringic acid was kindly provided by Dr K. Haider, Institut für Biochemie des Bodens, Braunschweig, FRG.

Media and culture conditions. The basal medium used was that of Eriksson \& Goodell (1974) with cellulose replaced by glucose. It was sterilized by autoclaving at $121{ }^{\circ} \mathrm{C}$ for $20 \mathrm{~min}$, except for the glucose which was sterilized separately. The aromatic compounds were added as filter-sterilized solutions of their sodium salts to give

† Present address: Department of Microbiology, Panjab University, Chandigarh 160014, India. 
final concentrations of $1 \mathrm{~mm}(0.5 \mathrm{~mm}$ in the case of methyl gallic acid). These compounds were added at the beginning of the incubation. The yeast was precultured on yeast extract/malt extract broth (Difco) for $40 \mathrm{~h}$. After two washes with sterile $0.9 \% \mathrm{NaCl}$ about $10^{7}$ cells were then added to $20 \mathrm{ml}$ basal medium in a $200 \mathrm{ml}$ baffled Erlenmeyer flask and incubated at $30^{\circ} \mathrm{C}$ on a rotary shaker (130 r.p.m.).

For the study of labelled syringic acid decarboxylation by whole cells $10 \cdot 7 \mathrm{MBq}\left[\right.$ carboxy- $\left.{ }^{14} \mathrm{C}\right]$ syringic acid (specific activity $1.07 \mathrm{GBq} \mu \mathrm{mol}^{-1}$ ) was added to the flask (as a solution in $10 \mu \mathrm{l}, N$-dimethylformamide). The flask was closed with a silicone rubber stopper from which a tiny glass cup was suspended containing $0.5 \mathrm{ml} 10 \%$ $(w / v) ~ N a O H$ to absorb released ${ }^{14} \mathrm{CO}_{2}$ (Haider \& Trojanowski, 1975). This experiment was set up in triplicate. The cultures were shaken as before, and $0.5 \%$ glucose was added to one of the flasks after $24 \mathrm{~h}$. The $\mathrm{NaOH}$ was withdrawn every day and the cups were rinsed with $2 \mathrm{ml}$ distilled water into counting vials. After the addition of $10 \mathrm{ml}$ Instagel (Packard), radioactivity was measured in a liquid scintillation spectrometer.

For the cell-free enzymic decarboxylation of $\left[\right.$ carboxy- $\left.{ }^{14} \mathrm{C}\right]$ syringic acid cultures were grown on basal medium containing $0.5 \%$ glucose (uninduced) or $0.5 \%$ glucose $+1 \mathrm{~mm}$ unlabelled syringate (induced). Both cultures were harvested after the degradation of about $50 \%$ of the syringate (monitored by the decrease in absorbance of the supernatant at $262 \mathrm{~nm}$ ). The cells were centrifuged, washed with cold potassium phosphate buffer $(0 \cdot 1 \mathrm{M}, \mathrm{pH} 7 \cdot 0)$, disrupted in an X-press and centrifuged at $48000 \mathrm{~g}$ for $30 \mathrm{~min}$. The supernatant was used as a crude enzyme extract. The enzymic reaction was done in a $100 \mathrm{ml}$ Erlenmeyer flask with the same arrangement to $\operatorname{trap}^{14} \mathrm{CO}_{2}$ as in the growth experiment above. Protein was estimated by the Lowry method. Protocatechuate-3,4-oxygenase was assayed as described by Durham et al. (1980).

GC/MS analysis. The nature of the degradation products was established by combined GC/MS. A series of flasks was prepared and a single flask was removed for analysis at specific times. The cells were removed by centrifugation and the supernatant was adjusted to $\mathrm{pH} 2$ and extracted with ethyl acetate. The solvent was removed and the residue was reacted with $N$-methyl- $N$-trimethylsilyl trifluoroacetamide at $100{ }^{\circ} \mathrm{C}(10 \mathrm{~min})$ in a screw-cap vial to form trimethylsilyl derivatives. The mass spectrometer was a Kratos MS 25 combined with a Carlo Erba 2100 gas chromatograph. A sample $(1 \mu \mathrm{l})$ of the reaction mixture was injected onto a Chrompak CP Sil 5 quartz capillary column $(25 \mathrm{~m} \times 0.32 \mathrm{~mm})$ with $\mathrm{He}$ as carrier gas using a split ratio of $30: 1$. For elution a temperature programme was used : $40^{\circ} \mathrm{C}$ to $80^{\circ} \mathrm{C}$ at $3{ }^{\circ} \mathrm{C} \mathrm{min}-1$ and then to $240{ }^{\circ} \mathrm{C}$ at $10^{\circ} \mathrm{C} \mathrm{min}^{-1}$. Mass spectra were recorded at a trap current of $100 \mu \mathrm{A}$, an ionization energy of $70 \mathrm{eV}$ and with the ion source set at $200^{\circ} \mathrm{C}$. After interpretation of the mass spectra, structures were confirmed by comparison with authentic compounds.

Quantitative analysis of sinapic acid and its degradation products by HPLC. Samples $(0.5 \mathrm{ml})$ of the culture liquid were withdrawn and centrifuged to give a cell-free supernatant. The HPLC system consisted of two pumps (Waters M6000A) connected to a gradient programmer M680 (Waters), a U6K injector (Waters) and a HewlettPackard 1040 photo diode array detector. Samples $(10 \mu \mathrm{l})$ of the supernatant were injected into a Waters Resolve reverse-phase column $\left(15 \times 0.4 \mathrm{~cm}, 5 \mu \mathrm{m}\right.$ particles) at room temperature and with a flow rate of $1 \mathrm{ml} \mathrm{min}^{-1}$. Specific conditions for the measurements were as follows.

Sinapic acid degradation. Eluant, acetonitrile $/ 165 \mathrm{mM}$-acetic acid (in water) $(15: 85, \mathrm{v} / \mathrm{v})$; detector wavelength, $300 \pm 50 \mathrm{~nm} ; t_{\mathrm{R}}\left(\right.$ sinapic acid), $470 \mathrm{~s} ; t_{\mathrm{R}}$ (syringic acid), $214 \mathrm{~s} ; t_{\mathrm{R}}(3-O$-methyl gallic acid), $128 \mathrm{~s}$.

Syringic and 3-O-methyl gallic acid degradation. Eluant, acetonitrile/165 mM-acetic acid (in water) (10:90, $\mathrm{v} / \mathrm{v})$; detector wavelength, $280 \pm 50 \mathrm{~nm} ; t_{\mathrm{R}}\left(\right.$ syringic acid), $347 \mathrm{~s} ; t_{\mathrm{R}}\left(3-O\right.$-methyl gallic acid), $170 \mathrm{~s} ; t_{\mathrm{R}}($ gallic acid), $104 \mathrm{~s} ; t_{\mathrm{R}}$ (2,6-dimethoxy-1,4-benzoquinone), $318 \mathrm{~s}$.

Gallic acid degradation. Eluant, $165 \mathrm{~mm}$-acetic acid (in water); detector wavelength, $262 \pm 10 \mathrm{~nm} ; t_{\mathrm{R}}$ (gallic acid) $285 \mathrm{~s}$.

Concentrations were determined by integrating peak areas using a Shimadzu C-R $3 \mathrm{~A}$ integrator and by comparison with standard solutions of the corresponding compounds. The identity of the eluted compounds was confirmed by measuring UV and mass spectra of collected fractions and by comparison with authentic compounds.

\section{RESULTS}

\section{Degradation of sinapic acid by $R$. glutinis}

The degradation of sinapic acid in the presence of various concentrations of glucose is shown in Fig. 1. In the absence of glucose the degradation of sinapic acid was incomplete, but when the glucose concentration was increased from 0.1 to $1.0 \%$ catabolite repression was observed. The decrease in glucose concentration in the culture supernatants (Fig. 2) shows that while the organism started growing immediately (indicated by a decrease in glucose concentration), sinapic acid was not metabolized until the glucose concentration had fallen to a lower level. The specific growth rate on $1 \%$ glucose was the same in the presence $(1 \mathrm{~mm})$ and in the absence of sinapic acid (data not shown). The onset of sinapic acid degradation occurred at the beginning 


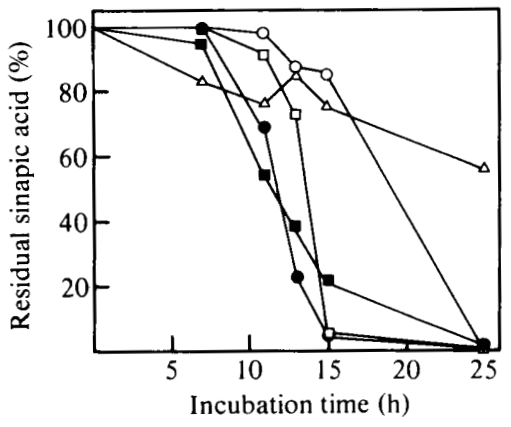

Fig. 1

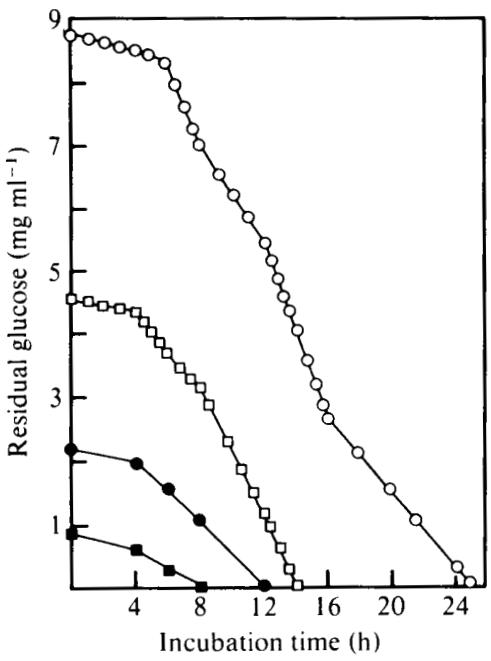

Fig. 2

Fig. 1. Sinapic acid degradation at various glucose concentrations during growth of $R$. glutinis. $\triangle$, No glucose; $\square, 0.1 \%$ glucose; $0,0.25 \%$ glucose; $\square, 0.5 \%$ glucose; $O, 1.0 \%$ glucose.

Fig. 2. Depletion of glucose in the presence of sinapic acid during growth of R. glutinis. $\square, 0 \cdot 1 \%$ glucose;, $0.25 \%$ glucose; $\square, 0.5 \%$ glucose; $O, 1.0 \%$ glucose.<smiles>COc1cc(C=CC(=O)O)cc(OC)c1O</smiles>

I<smiles>COc1cc(C(=O)O)cc(OC)c1O</smiles>

Il<smiles>COc1cc(C(=O)O)cc(O)c1O</smiles>

III<smiles>O=C(O)c1cc(O)c(O)c(O)c1</smiles>

IV<smiles>COC1=CC(=O)C=C(OC)C1=O</smiles>

$\mathrm{V}$

Fig. 3. Compounds identified in the supernatant of cultures of $R$. glutinis grown with sinapic acid. I, Sinapic acid; II, syringic acid; III, 3-O-methyl gallic acid; IV, gallic acid; V, 2,6-dimethoxy-1,4benzoquinone.

of the exponential phase (after about $4 \mathrm{~h}$ ). Using HPLC and GC/MS, sinapic acid was shown to be degraded to syringic acid, 3-O-methyl gallic acid, gallic acid and 2,6-dimethoxy-1,4benzoquinone (Fig. 3). Fig. 4 shows the formation of syringic acid from sinapic acid in the presence of $0.25 \%$ glucose. The syringic acid concentration was at a maximum after $16 \mathrm{~h}$.

\section{Degradation of sinapic acid intermediates}

R. glutinis was unable to metabolize syringic acid unless glucose was present as a cosubstrate (Fig. 5). With $0.1 \%$ glucose degradation was incomplete while no syringic acid was left after incubation for $14 \mathrm{~h}$ with higher glucose concentrations. Methyl gallic acid and gallic acid were 


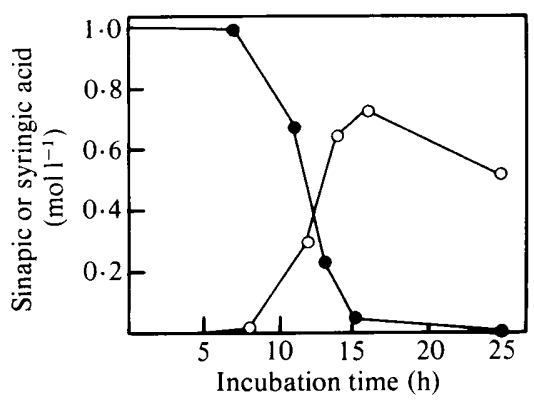

Fig. 4

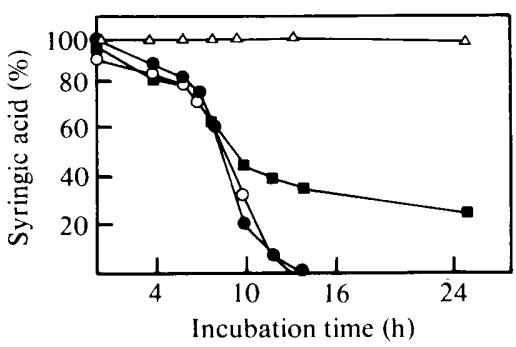

Fig. 5

Fig. 4. Formation of syringic acid $(O)$ from sinapic acid $(\bigcirc)$ during growth of $R$. glutinis (glucose concentration $0.25 \%$ ).

Fig. 5. Syringic acid degradation at various glucose concentrations during growth of $\boldsymbol{R}$. glutinis. $\triangle$, No glucose;, $0.1 \%$ glucose; $0,0.25 \%$ glucose; $O, 1 \cdot 0 \%$ glucose.

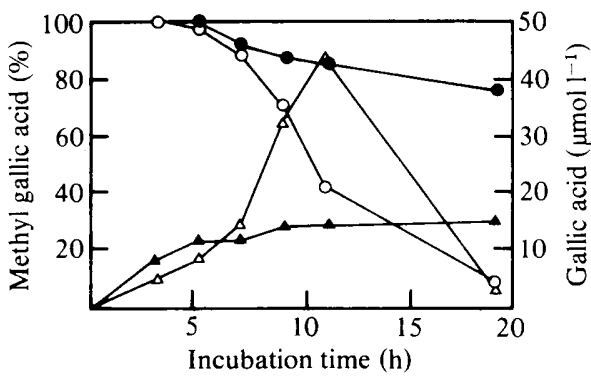

Fig. 6

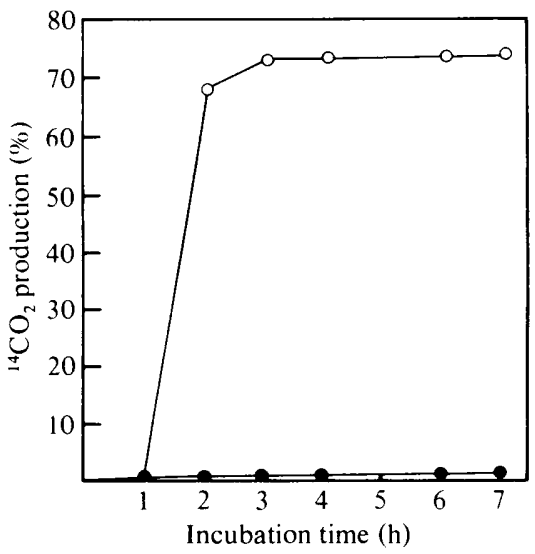

Fig. 7

Fig. 6. Formation of gallic acid $(\triangle, \Delta)$ from methyl gallic acid $(O, \bigcirc)$ by $R$. glutinis in the presence $(\triangle, O)$ or absence $(\Lambda, O)$ of $0.25 \%$ glucose.

Fig. 7. ${ }^{14} \mathrm{CO}_{2}$ production from [carboxy-14 $\left.\mathrm{C}\right]$ syringic acid by $R$. glutinis in the presence $(\mathrm{O})$ or absence (O) of $0 \cdot 25 \%$ glucose.

identified as the products of sinapic acid degradation. Methyl gallic acid was converted to gallic acid in the presence of glucose indicating that energy was required to remove the remaining methyl group from the ring. The gallic acid formed was quickly metabolized and therefore remained at a low concentration in the medium (Fig. 6).

\section{Studies with [carboxy- $\left.{ }^{14} \mathrm{C}\right]$ syringic acid}

The importance of glucose for the degradation of syringic acid was further confirmed in experiments using [carboxy ${ }^{14} \mathrm{C}$ ]syringic acid. There was no release of ${ }^{14} \mathrm{CO}_{2}$ from control cultures incubated in the absence of glucose (Fig. 7). Addition of glucose after $1 \mathrm{~d}$ resulted in a large release of ${ }^{14} \mathrm{CO}_{2}$. Whether this release was the result of the action of a single decarboxylase was investigated using cell-free extracts incubated with labelled syringic acid. The data in Table 1 show that there was a fourfold increase in enzyme activity in induced cells (measured as ${ }^{14} \mathrm{CO}_{2}$ release) and that $\mathrm{NADH}$ was the preferred coenzyme. No release of ${ }^{14} \mathrm{CO}_{2}$ occurred in the absence of coenzyme. 
Table $1 .{ }^{14} \mathrm{CO}_{2}$ production $\left[\right.$ d.p.m. $\left.(\mathrm{mg} \text { protein })^{-1}\right]$ from $\left[\right.$ carboxy $\left.-{ }^{14} \mathrm{C}\right]$ syringic acid by crude
extracts of $R$. glutinis

Decarboxylation was measured in a total volume of $2.9 \mathrm{ml} 0.2 \mathrm{~mm}$-potassium phosphate buffer, $\mathrm{pH} 7 \cdot 0$, containing $1.48 \mathrm{kBq}$ [carboxy-14 $\mathrm{C}$ ]syringic acid (added as a solution in $5 \mu \mathrm{l} N, N$-dimethylformamide). The coenzyme concentration was $3 \mu \mathrm{M}$. The assay contained $3.82 \mathrm{mg}$ enzyme protein (induced) or $3.17 \mathrm{mg}$ (uninduced).

$\begin{array}{lcr}\text { Coenzyme } & \text { Not induced } & \text { Induced } \\ \text { None } & 9.5 & 18.5 \\ \text { NADH } & 482.9 & 2072.8 \\ \text { NADPH } & 201.6 & 925.0\end{array}$

\section{DISCUSSION}

The degradation of sinapic acid by $R$. glutinis apparently occurred in two steps. The first metabolite, syringic acid, was formed either by shortening of the side chain forming syringaldehyde or through a $\beta$-oxidation type of reaction. From the intermediates identified, the question could not be answered as to which of these two pathways was operative in this yeast. Both pathways have been shown to be operative in different organisms growing on similar substrates. Vollmer et al. (1965) found that benzoic acid was formed from cinnamic acid by $\beta$-oxidation while Toms \& Wood (1970), French et al. (1976) and Gupta et al. (1981) reported shortening of the side chain of similar compounds. Kamaya \& Higuchi (1984) found that 3,4-dimethoxycinnamyl alcohol was first oxidized to veratryl glycerol and then cleaved between $C-\alpha$ and $C-\beta$ to give veratraldehyde. The degradation of sinapic acid in the absence of glucose and the complete metabolism of sinapic acid at a low glucose concentration $(0 \cdot 1 \%)$ showed that additional energy was available from the C-2-unit cleaved from the sinapic acid side chain.

Energy was required for the second stage of sinapic acid conversion, the degradation of syringic acid and methyl gallic acid. Apparently, $R$. glutinis cannot bring about ring cleavage unless all methoxy groups are converted into hydroxyl groups by demethylation. Therefore, syringic acid has to be metabolized to methyl gallic acid and further to gallic acid before ring cleavage can occur. The situation is similar in Sporotrichum pulverulentum (Eriksson et al., 1984), where syringic acid was shown to be metabolized via a trihydroxy intermediate. Iyayi \& Dart (1982) also proposed catabolism of syringic acid via gallic acid by the fungus Schizophyllum commune but they did not find methyl gallic acid as an intermediate. They suggested that both methyl groups were removed simultaneously. Using the yeast Trichosporon cutaneum for the degradation of benzoic acid it was also shown that ring cleavage only occurred after the formation of gallic acid by successive hydroxylations of the benzene ring (Anderson \& Dagley, 1980). In this organism protocatechuate dioxygenases could not be found. Our investigations, however, showed that $R$. glutinis does contain protocatechuate-3,4-dioxygenase (results not shown). It is also present in other species of Rhodotorula (Cain et al., 1968; Durham et al., 1984). The bacterium Pseudomonas putida was shown to have a different degradation pattern (Sparnins \& Dagley, 1975). It can cleave the ring of syringic acid after removal of only one of the two methyl groups indicating a difference between bacteria and fungi in the degradation of methoxylated aromatic acids.

The identification of 2,6-dimethoxy-1,4-benzoquinone in cultures indicated the presence of an oxidative decarboxylase (hydroxylase) enzyme which forms the hydroquinone precursor of the above quinone from syringic acid. Leonowicz et al. (1984) showed that extracellular laccases from two fungi were able to form the same hydroquinone from syringic acid. The intracellular NADH-dependent enzyme in $R$. glutinis is presumably not a laccase or a phenol oxidase. Formation of the same hydroquinone from syringic acid has been shown to occur in plant cells (Bolkart \& Zenk, 1968). A hydroxylase similar to the one reported here but acting on vanillic acid was described in Sporotrichum pulverulentum (Buswell et al., 1979, 1981). 


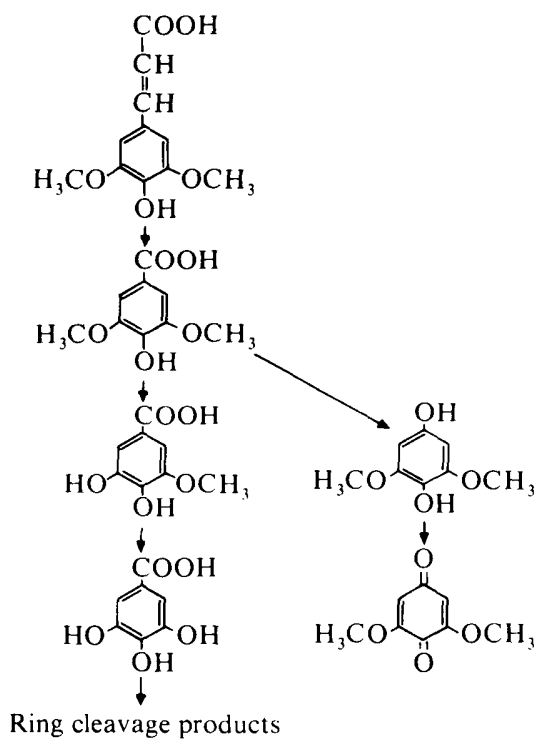

Fig. 8. Proposed sequence of reactions for the degradation of sinapic acid by $R$. glutinis.

Based on the identification of the metabolites and the presence of the hydroxylase, a scheme of reactions for the degradation of sinapic acid by $R$. glutinis is proposed (Fig. 8).

This work was supported by a grant from the Alexander von Humboldt Foundation to one of the authors (J.K.G.). The labelled syringic acid was a generous gift from Dr K. Haider. We thank Professors H. Sahm, H. Kern and Dr L. Eggeling for their helpful discussions.

This paper is dedicated to Professor Dr E. Bayer's 60th birthday.

\section{REFERENCES}

ADLER, E. (1977). Lignin chemistry - past, present and future. Wood Science and Technology 11, 169-218.

ANDERSON, J. J. \& DAGLEY, S. (1980). Catabolism of aromatic acids in Trichosporon cutaneum. Journal of Bacteriology 14, 534-543.

BolKarT, K. H. \& ZENK, M. H. (1968). Biosynthesis of methoxylated phenols in higher plants. Zeitschrift für Pflanzenphysiologie 59, 439-444.

Buswell, J. A., Ander, P., Petterson, B. \& EriksSON, K.-E. (1979). Oxidative decarboxylation of vanillic acid by Sporotrichum pulverulentum. FEBS Letters 103, 98-101.

Buswell, J. A., Eriksson, K.-E. \& Petterson, B. (1981). Purification and partial characterization of vanillate hydroxylase (decarboxylating) from Sporotrichum pulverulentum. Journal of Chromatography 215, 99-108.

Cain, R. B., Bilton, R. F. \& Darrah, J. A. (1968). The metabolism of aromatic acids by microorganisms. Biochemical Journal 108, 797-832.

Durham, D. R., Stirling, L. A., Ornston, L. N. \& PERRY, J. J. (1980). Intergeneric evolutionary homology revealed by study of protocatechuate 3,4dioxygenase from Azotobacter vinelandii. Biochemistry 19, 149-155.

Durham, D. R., McNamee, C. G. \& Stewart, D. B. (1984). Dissimilation of aromatic compounds in
Rhodotorula graminis: biochemical characterization of pleiotropically negative mutants. Journal of Bacteriology 160, 771-777.

ErIKsson, K.-E. \& Goodell, E. W. (1974). Pleiotropic mutants of wood rotting fungus Polyporus adustus lacking cellulase, mannase and xylanase. Canadian Journal of Microbiology 20, 371-378.

ERIKsSON, K.-E., GuPTA, J. K., Nishida, A. \& RAO, M. (1984). Syringic acid metabolism by some white-rot, soft-rot and brown-rot fungi. Journal of General Microbiology 130, 2457-2464.

French, C. J., Vance, C. P. \& Towers, G. H. N. (1976). Conversion of $p$-coumaric acid to $p$-hydroxybenzoic acid by cell free extracts of potato tubers and Polyporus hispidus. Phytochemistry 15, 564-566.

Gupta, J. K., Hamp, S. G., Buswell, J. A. \& ERIKSSON, K.-E. (1981). Metabolism of trans-ferulic acid by the white-rot fungus Sporotrichum pulverulentum. Archives of Microbiology 128, 349-354.

HaIDER, K. \& TrojanowsKI, J. (1975). Decomposition of specifically ${ }^{14} \mathrm{C}$-labelled phenols and dehydropolymers of coniferyl alcohol as models for lignin degradation by soft- and white-rot fungi. Archives of Microbiology 105, 33-41.

IYAYI, C. B. \& DART, R. K. (1982). Degradation of sinapyl alcohol by the fungus Schizophyllum commune. Microbios 34, 167-176. 
JAIN, S. (1981). Biodegradation of lignin and lignin monomer-syringic acid by some isolates. MSc thesis, Panjab University, Chandigarh, India.

Kamaya, Y. \& Higuchi, T. (1984). Metabolism of 3,4dimethoxycinnamyl alcohol and derivatives by Coriolus versicolor. FEMS Microbiology Letters 24, 225229.

Leonowicz, A., Edgehill, R. U. \& BollaG, J. M. (1984). The effect of $\mathrm{pH}$ on the transformation of syringic and vanillic acids by the laccases of Rhizoctonia and Trametes versicolor. Archives of Microbiology 137, 89-96.

Nimz, H. (1974). Birch lignin - proposal of a constitutional scheme. Angewandte Chemie 86, 336-344.

Ramirez, C. \& Gonzalez, A. (1984). Rhodotorula grinbergsii sp. nov. isolated from decayed wood in the evergreen rainy Valdivian forest of southern Chile. Mycopathologica 88, 51-54.
Sparnins, V. L. \& Dagley, S. (1975). Alternative routes of aromatic catabolism in Pseudomonas acidovorans and Pseudomonas putida: gallic acid as a substrate and inhibitor of dioxygenases. Journal of Bacteriology 124, 1374-1381.

Toms, A. \& WoOD, J. M. (1970). The degradation of trans-ferulic acid by Pseudomonas acidovorans. Biochemistry 9, 337-343.

VOllmer, K. O., Reisener, H. J. \& Grisebach, H. (1965). The formation of acetic acid from $p$ hydroxycinnamic acid during its degradation to $p$ hydroxybenzoic acid in wheat shoots. Biochemical and Biophysical Research Communications 21, 221225 .

WALKER, N. (1973). Metabolism of chlorophenols by Rhodotorula glutinis. Soil Biology and Biochemistry 5, 525-530. 